\title{
TRANSORAL APPROACH TO THE CRANIOVERTEBRAL JUNCTION
}

\author{
José Alberto Landeiro', Sávio Boechat', \\ Daniel de Holanda Christoph", Mariângela Barbi Gonçalves², \\ Igor de Castro 3 , Mario Alberto Lapenta ${ }^{3}$, Carlos Henrique Ribeiro ${ }^{3}$
}

\begin{abstract}
The transoral approach provides a safe exposure to lesions in the midline and the ventral side of the craniovertebral junction. The advantages of the transoral approach are 1) the impinging bony pathology and granulation tissue are accessible only via the ventral route; 2 ) the head is placed in the extended position, thus decreasing the angulation of the brainstem during the surgery; and 3) surgery is done through the avascular median pharyngeal raphe and clivus. We analyzed the clinical effects of odontoidectomy after treating 38 patients with basilar invagination. The anterior transoral operation to treat irreducible ventral compression in patients with basilar invagination was performed in 38 patients. The patients' ages ranged from 34 to 67 years. Fourteen patients had associated Chiari malformation and eight had previously undergone posterior decompressive surgery. The main indication for surgery was significant neurological deterioration. Symptoms and signs included neck pain, myelopathy, lower cranial nerve dysfunction, nystagmus and gait disturbance. Extended exposure was performed in 24 patients. The surgery was beneficial to the majority of patients. There was one death within 10 days of surgery, due to pulmonary embolism. Postoperative complications included two cases of pneumonia, three cases of oronasal fistula with regurgitation and one cerebrospinal fluid leak. In patients with marked ventral compression, the transoral approach provides direct access to the anterior face of the craniovertebral junction and effective means for odontoidectomy.
\end{abstract}

KEY WORDS: basilar invagination, odontoidectomy, transoral approach.

\begin{abstract}
Acesso transoral para a junção craniocervical
RESUMO - O acesso transoral é uma via direta e segura às lesões situadas na linha média e na face anterior da junção craniocervical. As vantagens do acesso transoral são as seguintes:1) a compressão óssea e o tecido de granulação localizam-se anteriormente e são accessíveis pela via anterior; 2) a cabeça do paciente é colocada em extensão, diminuindo a angulação do tronco cerebral durante a cirurgia; e 3) a cirurgia é feita através de um plano avascular na linha média faríngea e clivo. Analisamos os resultados obtidos após odontoidectomia por via transoral em 38 pacientes portadores de invaginação basilar. Trinta e oito pacientes com compressão ventral da junção craniocervical foram submetidos a odontoidectomia por via transoral. A idade dos pacientes variou de 34 a 67 anos. Quatorze pacientes apresentavam associação com malformação de Chiari tipo I e 8 já haviam sido submetidos à cirurgia descompressiva por via posterior. A maioria dos pacientes apresentou nucalgia, mielopatia, déficits dos nervos cranianos baixos, nistagmo, e distúrbio da marcha. Em 24 pacientes foi necessário ampliar o acesso transoral através de miotomia do palato mole, ou osteotomia do palato duro ou maxilotomia. A cirurgia proporcionou melhora dos sintomas na maioria dos pacientes. Um paciente faleceu no pós-operatório imediato por causa de embolia pulmonar. Dois pacientes tiveram pneumonia, três apresentaram fístula oronasal com regurgitação, e um teve fístula liquórica. Em pacientes com compressão ventral irredutível da junção craniocervical, a via transoral proporcionou uma abordagem direta e ampla ao processo odontoide.
\end{abstract}

PALAVRAS-CHAVE: invaginação basilar, odontoidectomia, acesso transoral.

The transoral approach (TOA) provides the most direct access to pathologies located on the ventral side of the craniovertebral junction (CVJ) ${ }^{1-6}$. The CVJ comprises a bony channel formed by the foramen magnum, the atlas and the axis that encloses the distal medulla oblongata, the myelobulbar junction and

\footnotetext{
${ }^{1}$ Chefe do Serviço de Neurocirurgia do Hospital da Força Aérea do Galeão, Rio de Janeiro RJ, Brasil, Professor Associado do Departamento de Cirurgia Geral e Especializada da Faculdade de Medicina da Universidade Federal Fluminense; ${ }^{2}$ Residente do Serviço de Neurocirurgia do Hospital da Força Aérea do Galeão, RJ; ${ }^{3}$ Assistente do Serviço de Neurocirurgia do Hospital da Força Aérea do Galeão, RJ.
}

Received 28 February 2007, received in final form 29 August 2007. Accepted 4 September 2007.

Dr. José Alberto Landeiro - Avenida Monsenhor Ascâneo 501 / 204 - 20621-06o Rio de Janeiro RJ - Brasil. E-mail: jalandeiro@gmail.com 
the upper cervical cord. Bone junction abnormalities at the CVJ are likely to compress and affect the local neural and vascular structures, and cerebrospinal fluid circulation.

We review the indications and the surgical technique of transoral approachs based on the experience acquired with the surgical treatment of 38 patients with basilar invagination. Stabilization is not emphasized in this paper.

\section{METHOD}

Thirty-eight patients with basilar invagination were operated on by the senior author between 1994 and 2004. Patients treated via the transoral approach for other conditions (rheumatoid arthritis, tumors and trauma) were excluded from this report.

Preoperative evaluation - Preoperative neuroimaging investigations consisted of plain radiographs followed by dynamic polytomography. The computerized tomography (CT) with tridimensional reconstruction and magnetic resonance imaging (MRI) provide a perfect visualization of the physiopathology of the lesion.

Preoperative evaluation also included orthodontal examination, detection of oropharyngeal infection, the nutritional condition of the patient and the functional state of lower cranial nerves. Poorly nourished patients were first treated with enteral feeding. Patients with lower cranial nerve deficits had tracheostomies during preoperative treatment.

All patients started the neurodiagnostic procedures with thin section computed tomography (CT) scans in coronal, axial and sagittal views followed by MRI scans in the flexed and extended positions in order to verify stability.

Surgical procedure - The patient was positioned supine with the head slightly extended and secured in the Mayfield support with three-point skull fixation, with the operating table placed in a slight Trendelenburg position. The surgeon stood behind or on the right side of the patient. Usually tracheostomy was not necessary; a nasotracheal armored tube provided adequate ventilation. The use of self-retaining retractors facilitated the surgery. The tongue and endotracheal tube were depressed, and the soft palate elevated and compressed backwards, assisted by two nasal tubes fixed to the palate. High upward migration of the odontoid process may require incision of the soft palate, avoiding the uvula (Fig 1). The use of teeth protectors was useful and helped to fix the retractor.

The palpated anterior tubercle of the atlas was an important landmark for the incision, because it is usually located in the center of the lesion. Therefore, an incision of $2.5 \mathrm{~cm}$ above and below the atlas tubercle was usually sufficient to reach the inferior border of the clivus and the body of the axis. A midline incision in the posterior mucosa and the pharyngeal muscles was done in one single plane up to the anterior longitudinal ligament.

The area of incision was infiltrated with 1:200000 solution of xylocaine with adrenaline to reduce mucosal bleed-

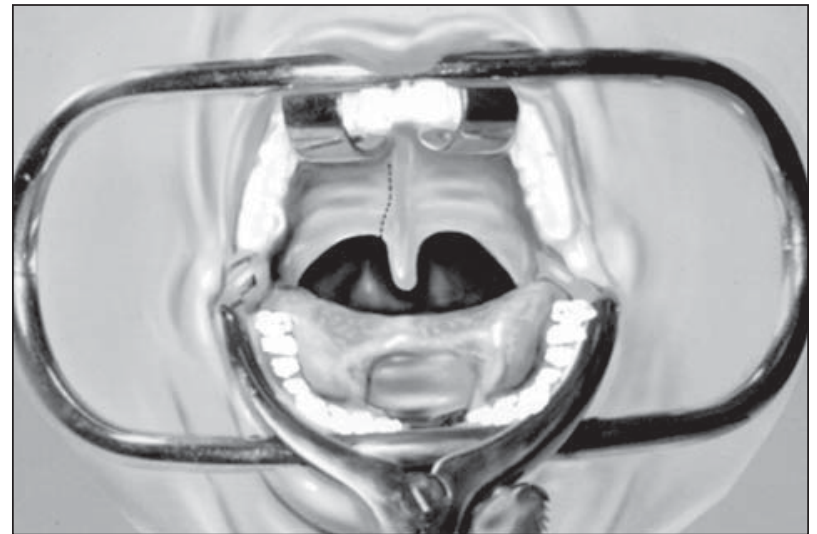

Fig. 1. Incising the soft palate to one side of the uvula.

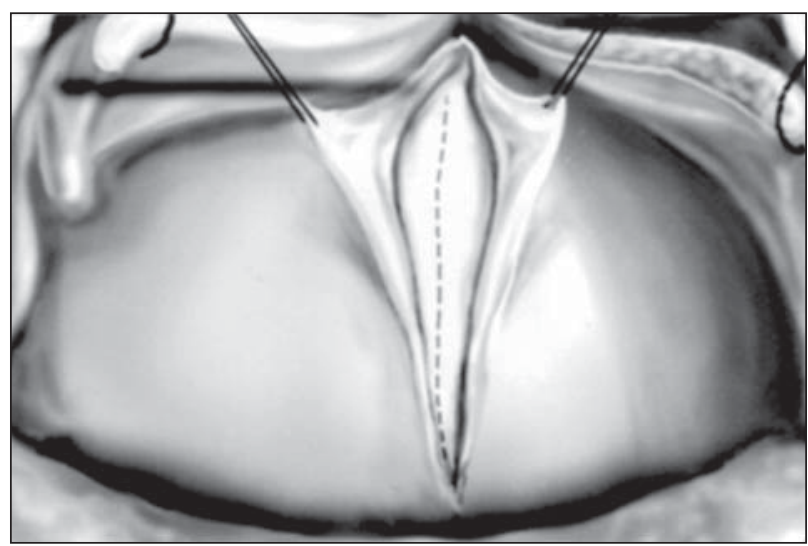

Fig 2. After infiltration, a midline incision is made in the pharyngeal mucosa. To allow for retraction, the incision should extend well above and below the lesion.

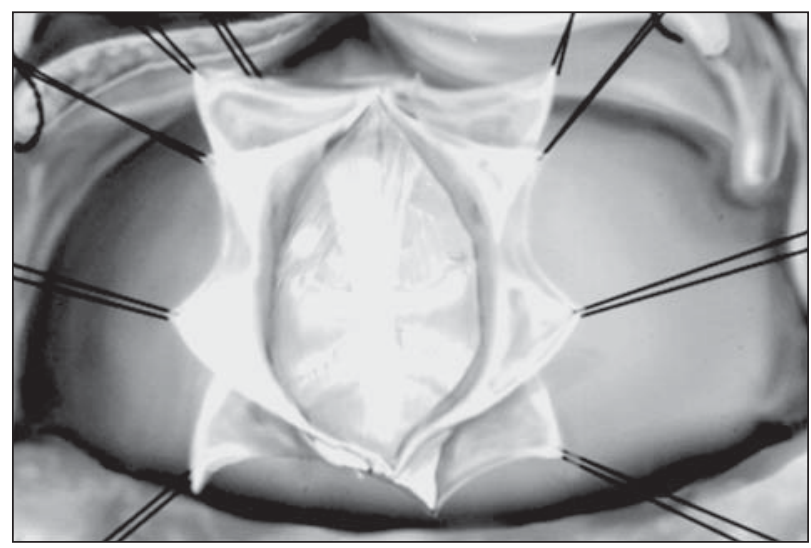

Fig 3. The ligaments and muscles are dissected from the bone. The switches retain the soft tissue.

ing. An operating microscope with 350 or $400 \mathrm{~mm}$ lenses was used at this point. After the incision, the pharyngeal muscles and mucosa were laterally retracted. With the aid of periosteal dissectors, the longitudinal ligaments were dissected from the bone, releasing the anterior facets of the $\mathrm{C}_{2}$ body, the arch of $\mathrm{C}_{1}$ and the inferior border of the clivus. 


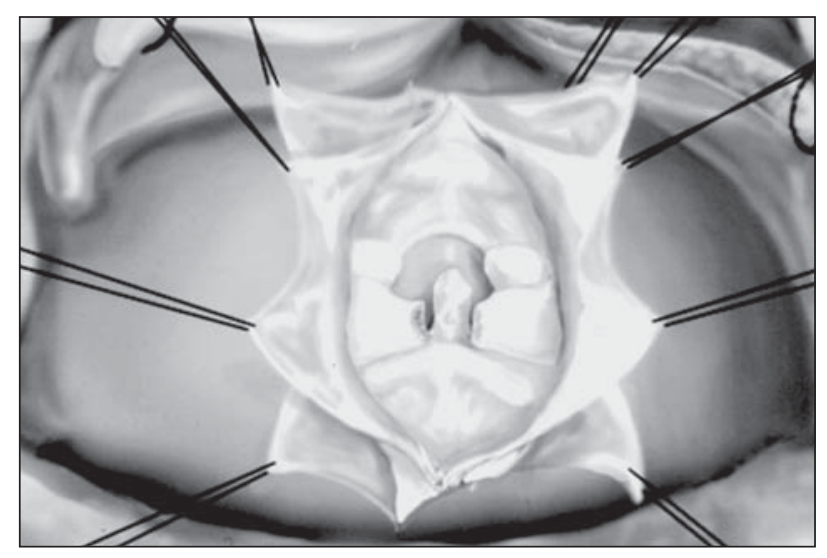

Fig 4. The clivus, arch of $C_{1}$ and the body of $C_{2}$ are exposed. Half of the anterior arch of $C_{1}$ has been removed.

The anterior tubercle of the arch of $C_{1}$ is the surgical key to the CVJ. The longus colli muscles are attached to it on both sides, and the anterior longitudinal ligament is attached in the midline. Intraoperative fluoroscopy can help in the localization of the $C_{1}$ tubercle and $C_{2}$ body. About 12-15 mm of the anterior arch of atlas was removed with the drill. This maneuver exposes the base of the odontoid process (Figs 2, 3 and 4). In severe invagination, it may be necessary to resect the caudal clival bone.

The odontoidectomy was performed with a highspeed drill with cutting bars until the posterior cortical was reached, which was subsequently removed by drilling with diamond burrs. Before drilling the posterior cortical bone, traction of the odontoid peg was performed, followed by section of the alar and apical ligaments, and resection by drilling or with a pituitary rongeur (Figs 5, 6 and 7). In order to achieve adequate decompression, the ligaments and the tectorial membrane were excised. The operation was completed when the pulsatile dura protruded ventrally into the decompression site. The cavity was then irrigated with antibiotic solution and the hemostasy was checked. The closure was performed in two layers, muscular and mucosal, with Vicryl 3.0 continuous stitches. In the case of myotomy of the uvula and the soft palate, closure was performed in three layers. The orogastric tube that was placed prior to the surgery was retained. A rigid neck collar was used until the stability of the CVJ was determined.

The patients remained intubated for 48 hours, with the removal of the tube done only after a functional study of

Table 1. Clinical findings.

\begin{tabular}{lc}
\hline & No. of patients \\
\hline Neck pain & 37 \\
Myelopathy & 31 \\
Sensory disturbance & 16 \\
Gait disturbance & 15 \\
Lower cranial nerve palsies & 7 \\
Nystagmus & 4 \\
Radiculopathy & 1 \\
\hline
\end{tabular}

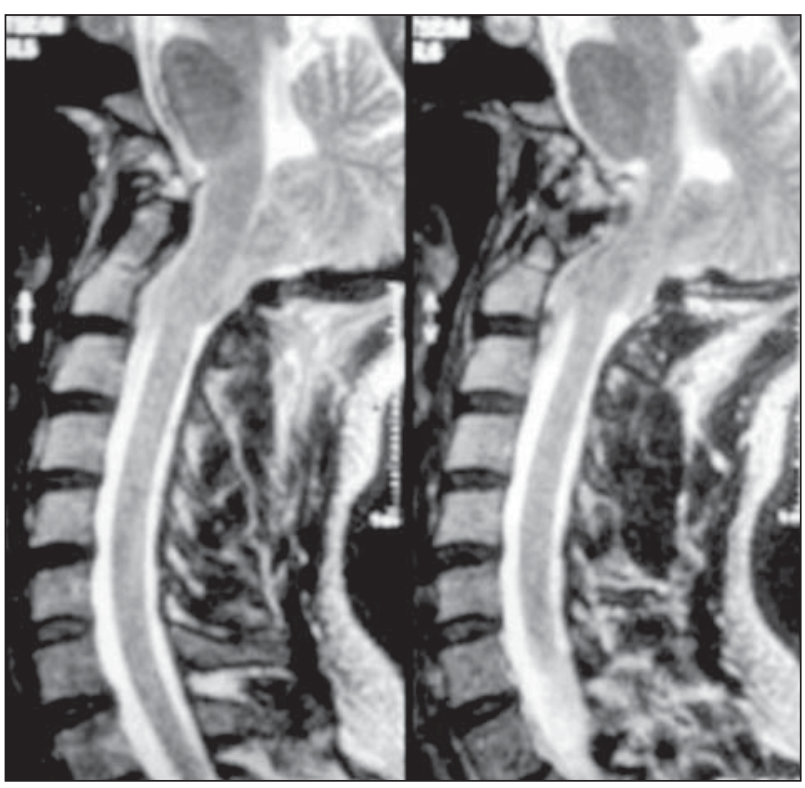

Fig 5. Midsagittal T2-weighted image at the craniovertebral junction showing intrusion of the odontoid peg into the foramen magnum and severe cervicomedullary junction compression.

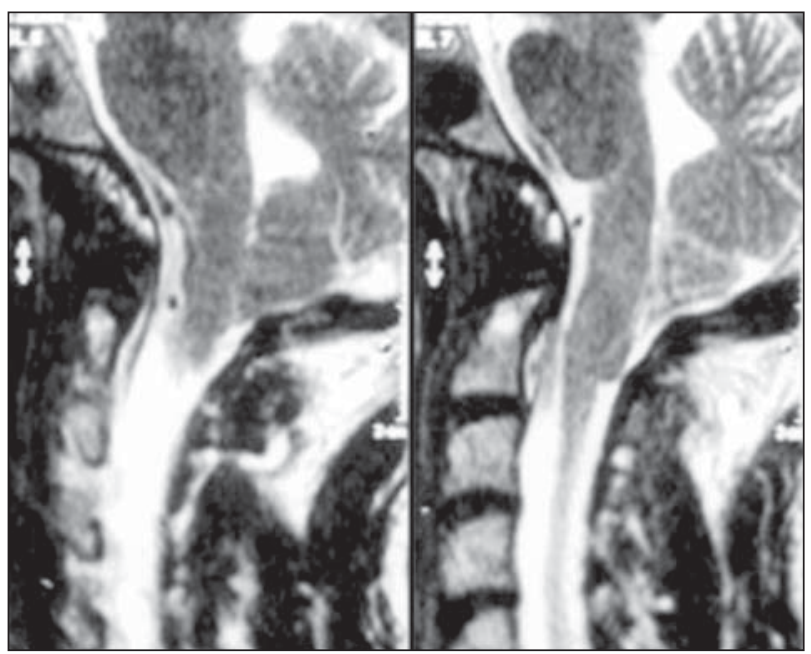

Fig 6. Midsagittal T2-weighted postoperative image, demonstrating removal of the odontoid process.

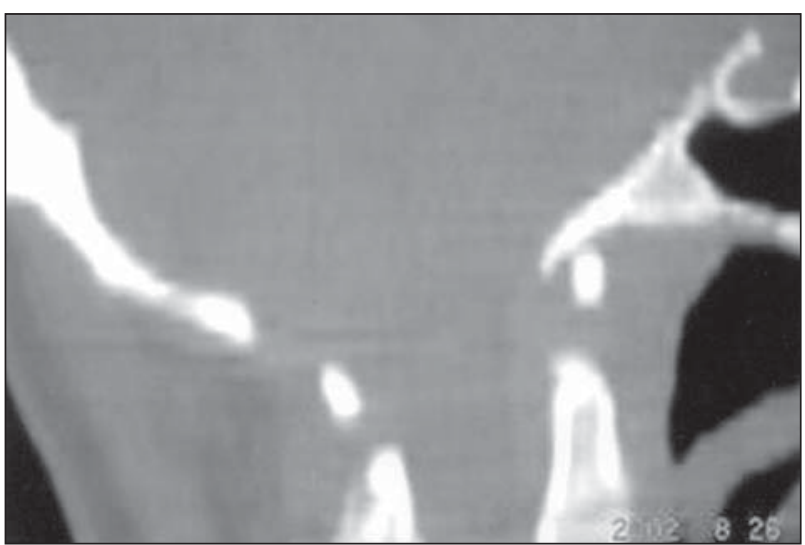

Fig 7. Postoperative CT scan in the sagittal view after odontoidectomy. The anterior ring of the atlas has been spared. 
Table 2. Postoperative neurological status.

\begin{tabular}{lccc}
\hline & Same & Improved & Worse \\
\hline Neck pain & 4 & 32 & - \\
Myelopathy & 19 & 14 & 3 \\
Gait disturbance & 15 & 11 & 3 \\
Lower cranial nerve palsies & 3 & 4 & - \\
Nystagmus & 2 & 2 & - \\
Radiculopathy & - & 1 & - \\
\hline
\end{tabular}

Table 3. Mortality, morbidity in the 38 patients who underwent a transoral approach.

\begin{tabular}{lc}
\hline & No. of cases \\
\hline Mortality (respiratory failure) & 1 \\
Morbidity (pulmonary infection) & 3 \\
CSF leak & 1 \\
Soft palate dehiscence & 3 \\
\hline
\end{tabular}

the larynx and pharynx. Tracheostomy was indicated in cases of postoperative lower cranial nerve deficits.

Postoperative care - The cicatrization of the mucosa did not present any problems. However, careful oral and nasal asepsis was crucial. The patient should not take any solids or fluids orally for approximately six days following surgery. During this period, nutrition and medication should be administered intravenously or through a feeding tube. Corticosteroids should be administered intravenously during the first three days, until labial, tongue and pharynx edema completely subsides.

\section{RESULTS}

Tables 1 and 2 show the clinical features and the postoperative evaluation. Thirty-eight patients were submitted to transoral decompression surgery. Twenty patients were male and eighteen female (mean age at surgery, $39.6 \mathrm{yrs}$; range, 38-67 yrs). A significant number of patients presented with neck pain and motor disturbances. Twenty-two patients were handicapped but still independent with limited activity. Eleven had severe neurological deficits and were in nursing care. Thirty-one patients had pyramidal signs; 16 had sensory disturbances; 12 had cerebellar signs such as gait disturbance and nystagmus; and seven had lower cranial nerve deficits. Specific signs such as short neck, and cervical hyperlordosis were seen in 27 patients.

All patients had basilar impression, nine had associated Chiari I malformation and five had associated syringomyelia. Partial or total assimilation of the atlas was observed in 20 patients, and irreducible ventral encroachment in 38 patients.
Postoperative results - The dens was removed in 38 patients. Two patients needed to be reoperated on because the odontoid peg had not been totally removed and the symptoms remained. Twenty-four patients required extended exposure. Soft palate myotomy was applied in 20 patients, two required maxillotomy and two required hard palate osteotomy. Table 3 shows the mortality, morbidity and complications. One patient died in the immediate postoperative period because of pulmonary embolism. Three patients had pulmonary infection, one developed CSF leakage, and a leak in the dura mater was detected and treated during the surgery. Dehiscence of soft palate requiring resuture occurred in three patients. One developed nasal regurgitation. Significant improvement in neurological deficits was observed in 14 patients and stabilization of the neurological deficits in 23 .

Stabilization - Of the 38 patients who underwent odontoidectomy in this series, 20 required a stabilization procedure. Lateral tomography in flexed and extended positions of the CVJ was done 10 days after surgery to determine craniocervical stability. Two patients had previously been operated on and the craniocervical junction was fixed with Luque/Hartshill rectangles. The other 18 patients were submitted to occiptocervical fixation with the inside-outside technique, originally developed by Pait et al. ${ }^{7}$.

\section{DISCUSSION}

The specific treatment used on patients with basilar invagination depends on whether the bone abnormality can be reduced to its normal position and also on the direction of the compression. The transoral approach should be restricted to the midline in patients with extradural pathologies. Anterior surgical decompression is indicated in patients with irreducible ventral compression of the cervicomedullary junction and can be extended by mobilization of the maxilla, incision of the soft palate and osteotomy of the hard palate. The enlarged transoral route allows a better approach to more extensive lesions in this 
region and in patients with higher upward migration of the odontoid process ${ }^{8-10}$.

TOA is now a well-established surgical procedure for anterior decompression at the $\mathrm{CVJ}^{1-3,5,6,11,12}$. This approach provides direct access to ventral lesions at the $\mathrm{CVJ}^{13-17}$ and has gained great acceptation after Menezes et al..$^{15-18}$ formulated physiological criteria and guidelines for treatment of certain disorders of the CVJ. Until recently, most CVJ malformations were treated by foramen magnum decompression and stabilization when unstable ${ }^{19,20}$.

Thirty-eight patients with basilar invagination underwent an odontoidectomy through TOA. Most patients presented with myelopathy and neck pain. The recovery level of patients depended on the magnitude of the preoperative deficits. Patients suffering from light myelopathy who could walk had a better recovery than those who could not. Patients who were unable to walk had their clinical conditions stabilized after surgery. Eleven of 15 patients who had gait disturbance recovered and four of seven who had cranial nerve disfunction improved after surgery. One patient died in the postoperative course because of pulmonary embolism and three developed pulmonary infection.

Although some authors mention the removal of intradural lesions through this approach, the major indication for this approach is in the treatment of extradural lesions due to complications originated from treating intradural lesions such as abscesses,

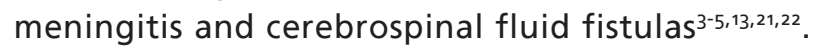
One patient in our series developed a cerebrospinal fluid fistula that was detected and closed during the surgery. However, problems encountered in these approaches included inadequate exposure of the lateral margins, lack of proximal control of the vertebral arteries and the possibility that incisions of the clival dura can lead to excessive hemorrhaging that can be difficult to control ${ }^{21}$.

On strictly technical grounds, many authors disagree on various points. For example, preoperative tracheostomy versus oral or nasal intubation, incision of soft palate or retraction, multilayer or single layer closure of the soft palate ${ }^{11,12}$. We close the posterior pharyngeal wall in two layers and the soft palate in three layers.

Soft-palate incision provides access to the lower clivus and the high $\mathrm{CVJ}^{15-18}$. This technique provides superior operative exposure compared to suture of the soft palate and its retraction into the nasal cavity. The enlarged TOA allows a better approach to more extensive lesions in this region, in cases with higher upward migration of odontoid process in patients in whom there is limited mandibular excursion ${ }^{1,8-10}$. However, an incision of the soft palate or osteotomy of hard palate has a high likelihood of complications such as dysphagia, nasal regurgitation and regurgitation with speech and swallowing. Enlarged access was necessary in most of our cases. The type of surgical procedure and whether it is necessary to enlarge the access through an incision of the soft palate, osteotomy of the hard palate, or eventual need for a maxillotomy or mandibular osteotomy, will depend on the analysis of a patient's pathology and on the study of preoperative imaging. The CT with bone landmarks and tridimensional reconstruction accompanied by MRI allows a good understanding of the physiopathology of the lesion. The imaging allows one to establish the relations of the odontoid process with the soft and hard palate, the extension of the vertical migration, the degree of subluxation and the condition of the neural tissue ${ }^{23}$. Three patients had soft palate dehiscence and required resuture and long term enteral nutrition.

The importance of tracheostomy should not be overemphasized. It allows prevention of postoperative respiratory complications and is a safeguard against airway obstruction from postoperative lingual edema. Preoperative tracheostomy was not performed in any case in our series. Postoperative tracheostomy was required in 10 cases because of the involvement of the lower cranial nerves and where prolonged intubation was required in the postoperative period.

An analysis of the instability of the CVJ is mandatory in the immediate postoperative stage $\mathrm{e}^{2,5,11,17}$. The following situations make the atlantoaxial complex vulnerable to dislocation: turning the anesthetized patient, transferring patients onto the bed or table, waiting for posterior fusion, particularly if traction is released and it is not immediately replaced. Therefore, we recommend extreme care with every patient after TOA. The large majority of patients that submit to an odontoidectomy become unstable and should be stabilized with rigid external braces until the internal fixation is completed ${ }^{11,16,17,24,25}$. Menezes et al. ${ }^{16}$ reported that, in large numbers of transoral operations, approximately $75 \%$ needed a dorsal fixation procedure after odontoidectomy. The segments needing fixation depended on a number of factors. For those patients in whom the anterior arch of the atlas and the transverse ligament remained intact, the fixation could be restricted to $C_{1} / C_{2}$. In those patients who submitted to resection of the transverse ligament or in 
whom the arch of the atlas was removed, fixation was mandatory. According to Menezes and Van Gilder ${ }^{17}$, when osteoarthritis was present in the atlantoaxial joints, posterior fixation was often not required. Although some authors mention ventral fixation ${ }^{26-28}$, posterior stabilization is more practical and safer ${ }^{7,29}$. Of 38 patients, 18 underwent a posterior fixation using an inside-outside technique as proposed by Pait et al. ${ }^{7}$ and two were already fixed with the Ransford loop technique ${ }^{29}$. The method of fixation with titanium plates allows artifact-free imaging with the CT and MRI scans for the postoperative period.

In conclusion, TOA allows direct access to the clivus, craniovertebral junction and the anterior aspects of the first three cervical segments. In principle, TOA is meant for ventral compressive lesions. The main indications for TOA are irreducible ventral compression, with the most common being basilar invagination.

\section{REFERENCES}

1. Appuzo MLJ, Weiss MH, Heiden JS. Transoral exposure of the atlantoaxial region. Neurosurgery 1978;3:201-207.

2. Crockard HA. The transoral approach to the base of the brain and upper cervical cord. Ann R Coll Surg Engl 1985;67:321-325.

3. Crockard HA, Bradford R. Transoral transclival removal of schwannoma anterior to the craniocervical junction. J Neurosurg 1985;62:293-295.

4. Bonkowski JJA, Gibson RD, Snape L. Foramen magnum meningioma; transoral resection with a bone baffle to prevent CSF leakage: case report. J Neurosurg 1990;72:493-496.

5. Crockard HA, Sen CN. The transoral approach for the management of intradural lesions at the craniovertebral junction: review of 7 cases. Neurosurgery 1991;28:88-98

6. Crockard HA, Johnston F. Development of transoral approaches to lesions of the skull base and craniovertebral junction. Neurosurg Quart 1993;3:61-82.

7. Pait TG, Al-Mefty O, Boop FA, Arnautovic KI, Rahman S, Ceola W. Insideoutside technique for posterior occiptocervical spine instrumentation and stabilization: preliminary results. J Neurosurg 1999;90(Suppl): S1-S7.

8. Anand VK, Harkey HL, Al-Mefty, O: Open door maxillotomy approach for lesions of the clivus. Skull Base Surg 1991;1:215-217.

9. Kanamori Y, Miyamoto K, Hosoe H, Fujitsuka H, Tatematsu N, Shin $\mathrm{K}$. Transoral approach using the mandibular osteotomy for atlantoaxial vertical subluxation in juvenile rheumatoid arthritis associated with mandibular micrognathia. J Spinal Disord Tech 2003;16:221-224.

10. Vishteh AG, Beals SP, Joganic EF, et al. Bilateral sagittal split mandibular osteotomies as an adjunct to the transoral approach to the anterior craniovertebral junction: technical note. J Neurosurg (Spine 2) 1999;90: 267-270.

11. Di Lorenzo N: Craniocervical junction malformation treated by transoral approach. A survey of 25 cases with emphasis on postoperative instability and outcome. Acta Neurochir (Wien) 1992;118:112-116.

12. Goel A, Bhatjiwale M, Desai K. Basilar invagination: a study based on 190 surgically treated patients. J Neurosurg 1998;88:962-968.

13. Drake CG. Management of aneurysms of posterior circulation. In: Youmans JR (Ed). Neurological surgery. Vol 2, Philadelphia, Saunders CO, 1973;787-806.

14. Hadley MN, Spetzler RF, Sonntag VKH. The transoral approach to the superior cervical spine: a review of 53 cases of extradural cervicomedullary compression. J Neurosurg 1989;71:16-23.

15. Menezes AH. Developmental and acquired abnormalities of the craniovertebral junction. In Van Gilder JC, Menezes AH, Dolan KD (Eds). The craniovertebral junction and its abnormalities. New York: Futura Publishing 1987:109-158.

16. Menezes AH, Van Gilder JC, Graf CJ, McDonnell DE. Craniocervical abnormalities: a comprehensive surgical approach. J Neurosurg 1980;63 444-445.

17. Menezes AH, Van Gilder JC. Transoral-transpharyngeal approach to the anterior craniocervical junction: ten-year experience with 72 patients. J Neurosurg 1988;69:895-903.

18. Sawin PD, Menezes AH. Basilar invagination in osteogenesis imperfecta and related osteochondrodysplasias: medical and surgical management. J Neurosurg 1997;86:950-960.

19. Da Silva J. Basilar impression and Arnold-Chiari malformation: surgical findings in 209 cases. Neurochirurgia 1992;35:189-195.

20. Zileli M, Cagli S. Combined anterior and posterior approach for managing basilar invagination associated with type I Chiari malformation. J Spinal Disord Tech 2002;15:284-289.

21. Sen CN, Sekhar LN. Surgical management of anteriorly placed lesions at the craniocervical junction-An alternative approach. Acta Neurochir (Wien) 1991;108:70-77.

22. Yamaura A, Makino H, Isobe K, Takashima T, Nakamura T, Takemiya S. Repair of cerebrospinal fluid fistula following transoral transclival approach to a basilar aneurysm. J Neurosurg 1979;50:834-836.

23. Pappas CTE, Rekate HL. Role of magnetic resonance imaging and three dimensional computerized tomography in cranio vertebral junction anomalies. Pediatric Neurosurg 1988;14:18-22.

24. Dickman CA, Crawford N, Brantley AGU, Sonntag VKH. Biomechanical effects of transoral odontoidectomy. Neurosurgery 1995;36:1146-1153.

25. Dickman CA, Locantro J, Fessler RG. The influence of transoral odontoid resection on stability of craniovertebral junction. J Neurosurg 1992;77:525-530.

26. Andrade JR, MacNab I. Anterior occipito-cervical fusion using an extrapharyngeal exposure. J Bone Joint Surg (Am) 1969;51:1621-1626.

27. Goel A, Karapurkar AP. Transoral plate screw fixation of the craniovertebral junction: a preliminary report. Br J Neurosurg 1994;8:743-745.

28. Vender JR, Harrison SJ, McDonnell DE. Fusion and instrumentation at C1-C3 via the high anterior cervical approach. J Neurosurg 2000;92(Suppl):S24-S29.

29. Ransford AO, Crockard HA, Pozo JL, Thomas NP, Nelson IW. Craniocervical instability treated by contoured loop fixation. J Bone Joint Surg (Br) 1986;68:173-177. 